\title{
Quatro movimentos de Foucault contre lui-même: imagens, discurso e militância no centro e nas margens da rua
}

\author{
Four movements from Foucault contre lui-même: \\ images, discourse and militancy in the centre and street sides
}

\author{
Jocenilson RIBEIRO \\ Universidade Federal de São Carlos (UFSCar)
}

\begin{abstract}
RESUMO: O presente texto se configura com uma leitura resenhada do documentário Foucault contre lui-même. Trata-se, na verdade, de um ensaio que se desenvolve com a articulação da leitura de algumas obras do filósofo francês com os temas apresentados no filme. O principal objetivo é refletir a partir de algumas ideias de Foucault acerca de temas do presente, avaliando a atualidade de seu pensamento em nosso tempo. A questão da rua aparece nesse texto como lugar em que o pensamento do autor emana para refletir a própria sociedade e seus conflitos com os diferentes modos de instauração do poder, seja no passado, seja ainda hoje. A rua e a cidade acabam sendo seu grande laboratório, o imenso e inesgotável arquivo onde Foucault fezse militante e pensador, ora no centro, ora nas margens.
\end{abstract}

PALAVRAS-CHAVE: Michel Foucault. Discurso. História. Poder. Rua.

\begin{abstract}
This text presents a reading of the reviewed documentary Foucault contre luimême. It is an essay that articulates reading of some works of the French philosopher with the themes presented in the film. The main objective is to reflect about present issues, taking into account some of Foucault's ideas, assessing the relevance of his thought for today. The issue of street appears in this text as a place in which the author's thought emanates to reflect their own society and their conflicts with the different forms of power, in the past or nowadays. The street and the city end up being his great laboratory, the immense and inexhaustible archive where Foucault became militant and thinker, sometimes in the center, sometimes in the margins.
\end{abstract}

KEYWORDS: Michel Foucault. Discourse. History. Power. Street.

\section{Do prólogo: uma introdução}

Une image traverse les frontières.

G. Didi-Huberman

Trinta anos depois de sua precoce morte, acometido pelo suposto mal do século $X X$ (a AIDS), Foucault ainda nos presenteia com sa pensée, sa personne (VEYNE, 2008): um legado que continuará rendendo uma arqueologia de saberes e reflexões. Em tempos de repensar e fazer pensar o lugar do homem na sociedade com Foucault, uma das grandes fontes de inspiração de inúmeros pensadores até hoje, surge em nossas telas um interessante documentário intitulado Foucault contre lui-même ${ }^{1}$, dirigido por François Caillat. São 52 minutos de ideias, reflexões, imagens fixas e em movimento, narração em voz-off, testemunhos de especialistas, tudo isso e mais intercalado a inquietantes fotografias, cenas de Maio de 68 , falas do próprio filósofo e um clássico número de Henry Murcell (1659-1695), preenchendo o silêncio dos museus e de imponentes bibliotecas francesas, que lhes servem de cenário.

\footnotetext{
${ }^{1}$ Documentário disponível em: <https://www.youtube.com/watch?v=fDbqoojXlyA>. Aceso em: 20 jun.2015.
} 
O documentário é estruturado em quatro movimentos, respeitando o gênero musical na composição de H. Murcell: variação sobre o poder; do pensador ao militante; que lugar para o homem e uma vida nas margens, um lugar no centro, além de um prólogo e um epílogo que amarram os laços da película. E é respeitando essa estrutura neste texto que desenvolveremos a análise deste filme, refletindo sobre os temas ali sinteticamente abordados e discutidos pelos pensadores, e permitindo-nos pensar com Foucault na atualidade de seu pensamento - um exercício em forma de ensaio-resenha.

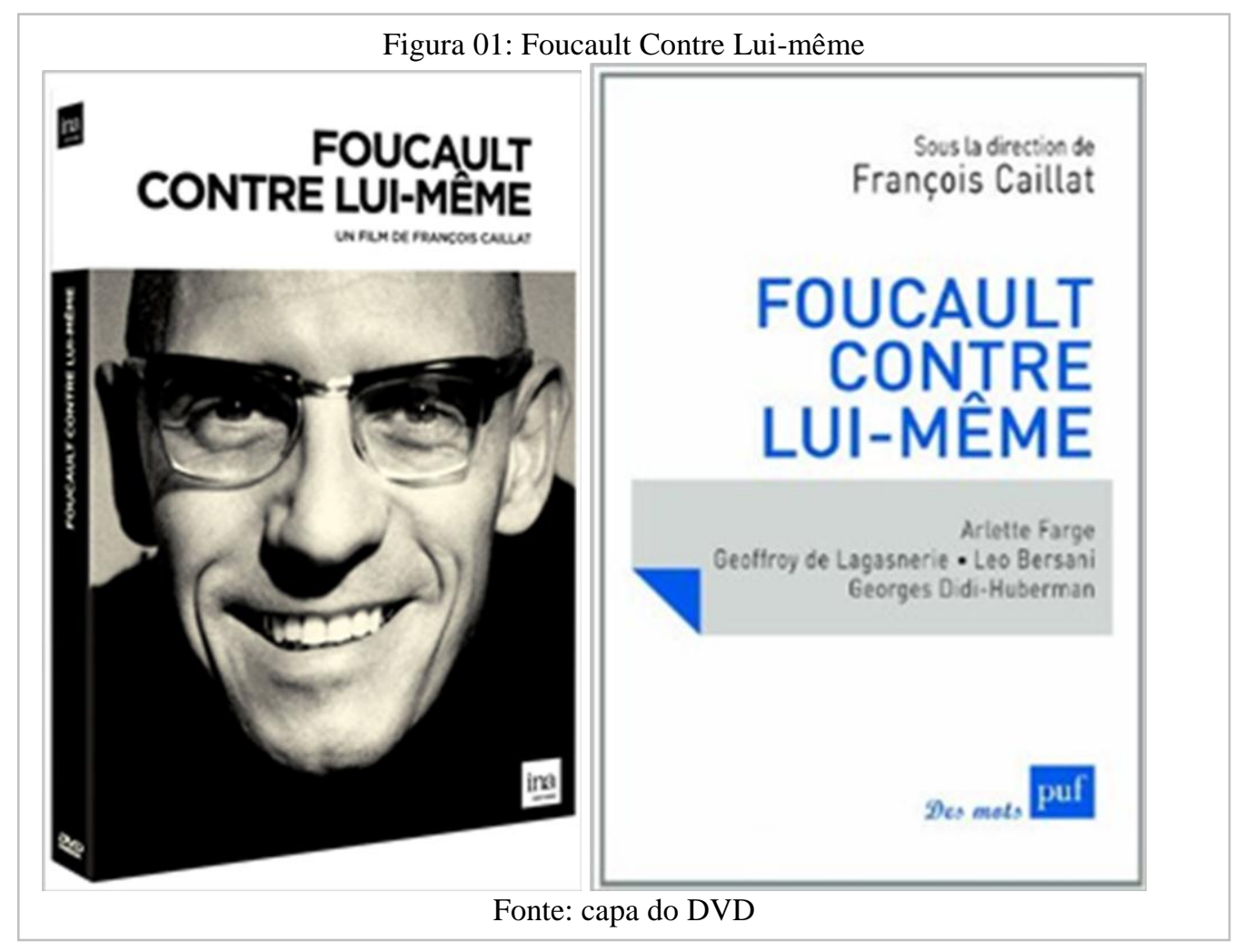

A película traz como complementos três entrevistas já de domínio público como Les mots et les choses (14'), realizada por Pierre Dumayet em 1966 na ocasião de publicação da obra homônima; Marx s'invite au café (21'), com Clavel e Glucksmann e outros intelectuais, de 1977; e Un tour d'horizon de la pensée Foucault (36') com André Berten difundido em 1981.

Em quase uma hora de questões provocadoras, problematizadas pelo "filósofo das margens", ouvimos interessantes depoimentos de vários pensadores. Alguns tiveram a chance de pensar com Foucault ainda vivo, como é o caso do filósofo e sociólogo Didier Eribon, da historiadora Arlete Farge, do filósofo e historiador das Artes Georges Didi-Huberman e do filósofo e crítico de literatura francesa, o norte-americano Léo Bersani, que fora convidado pelo próprio Michel Foucault para uma série de conferências no venerado Collège de France em 1982.

Entre esses estudiosos, figura o jovem sociólogo e filósofo francês Geoffroy de Lagasnerie, que aparece em primeiras cenas falando sobre a escrita foucaultiana como constituinte de sua ação permanente de pensador que buscava ir além de seu tempo, por vezes lutando contra ele mesmo. E o além do tempo dele é este em que vivemos agora quando temos a chance de discutir a atualidade de suas ideias e o que elas provocam para compreender o que somos hoje. 
Ao avaliar os 20 anos de um complexo, contraditório, incoerente e erudito trabalho foucaultiano, G. Lagasnerie reproduz o filósofo dizendo: "É o que Foucault chama de escrita. Ele diz que escrever é se transformar, é se desligar de si mesmo, é se afastar de si mesmo: se eu soubesse aonde eu iria, eu não escreveria." (02'17'. 02'34',).

G. Lagasnerie surgiu recentemente no cenário intelectual francês com novas leituras dos últimos trabalhos do filósofo, recorrendo ao curso Nascimento da biopolítica (1978-1979). Em 2012, concluiu um doutorado em sociologia na École des Hautes Études en Sciences Sociales, defendendo uma leitura neoliberal de Foucault. Publicado no mesmo ano, o livro ${ }^{2}$ resultante desse estudo suscitou notável polêmica na comunidade intelectual foucaultiana, tendo em vista que, a partir das últimas lições de Foucault no Collège de France, o principal objetivo de Legasnerie (2012) foi "mostrar como o filósofo francês teria se voltado aos teóricos formuladores do neoliberalismo alemão e norte-americano com a intenção de explorar a potencialidade crítica e emancipadora dessa doutrina contemporânea." (CARBONESI, 2014, p.195) Daí talvez se justifique a presença de uma nova voz provocante num momento de rememorar 30 anos sem, com e contra Foucault ao mesmo tempo e em nosso tempo.

\section{Primeiro movimento: variação sobre o poder}

A primeira parte do filme começa com a narração em voz-off introduzindo uma breve biografia intelectual do filósofo sob o tema da loucura e da desrazão no ocidente. Como já se sabe, este é um de seus principais objetos de interesse no início de seu percurso, vindo a público em 1961 com a publicação de História da loucura na idade clássica (Histoire de la folie à l'âge classique). Embora esse seja o trabalho que inscreva Foucault no cenário intelectual francês de fato inclinando o olhar de pensadores em ciências humanas para objetos "menores", o filósofo já havia marcado seu interesse pelo tema da loucura por meio da publicação de Doença mental $e$ psicologia (Maladie mentale et psychologie) em 1954. Mas o documentário inicia-se mesmo é com a obra oriunda de sua tese doutoral.

No filme, a loucura é mencionada enquanto objeto de estudo não como uma questão de saúde mental no olhar do filósofo, mas como um problema que se transformou ao longo dos séculos obedecendo a regras de transformações sujeitas a ordem de discursividades ao longo do tempo. Durante a Idade Média, até o fim do séc. XVII, o louco era um indivíduo que circulava livremente em meio a cidades e vilas sendo mais um sujeito aceito em sua comunidade; porém, a partir daí o louco, bem como homossexuais, pederastas, criminosos e vagabundos, começam a ser banidos da sociedade para prisões e asilos sob a ordem do rei.

Sensível às transformações pelas quais passava o tratamento dado ao louco e os modos de sua subjetivação, Foucault analisa a ruptura e os traços de continuidade que seguem tal tratamento procurando compreender os discursos que se instituíram como verdade da época. Foucault analisa, por exemplo, as mutações das técnicas penais da passagem do século XVIII para o XIX com intuito de compreender a emergência de diferentes modos e práticas de subjetivação constituídos pelo poder institucional. Assim, os sujeitos marginalizados e encarcerados são produzidos pelos discursos institucionalizados (igreja, escola, estado; medicina, clínica, ciência) construídos e reproduzidos no centro, em prol da ordem social. Nas palavras de G. Lagasnerie, o

\footnotetext{
${ }^{2}$ LAGASNERIE, G. La dernière leçon de Michel Foucault : Sur le néolibéralisme, la théorie et la politique. / LAGASNERIE, G. A última lição de Michel Foucault: sobre o neoliberalismo, a teoria e a política. Tradução de André Telles. São Paulo: Três Estrelas, 2013.
} 
poder vai produzir fronteiras e dividir a sociedade em dois espaços: um espaço interno, social, digno e racional e um espaço exterior, obscuro, irracional e excluído.

Face a problemática posta no primeiro movimento do documentário, diríamos que Foucault partiu de três elementos objetivos para delimitar metodologicamente seu objeto histórico-filosófico: um objeto concreto (a loucura, a prisão, o corpo, a sexualidade), um domínio geográfico (Ocidente, Europa, França, Asilos, Hospitais etc.) e um período cronológico historicamente determinados (Medievo, Séculos XVII, XVIII etc.). Tudo isso em função de uma história do presente com o objetivo de, através de análises discursivas, compreender o sujeito que nos tornamos na modernidade e na contemporaneidade. O filósofo afirma: "Eu diria que faço a história das problematizações, ou seja, história da maneira como as coisas se tornam problemas. Como e por que, e de que modo particular, a loucura se tornou um problema no mundo moderno. E por que isso se tornou um problema importante?" (4'31''-4'52',)

$\mathrm{Na}$ sequência do filme, o tema da sexualidade é apresentado como uma das primeiras problematizações foucaultianas que ganham corpo a partir de $1976 \mathrm{com}$ a publicação do primeiro volume de História da sexualidade - a vontade de saber (Histoire de la sexualité - la volonté de savoir). A obra vai evidenciar a questão do poder como dispositivo que intermedeia as relações intersubjetivas, materializando no corpo de homens e mulheres um novo ideal de feminilidade e virilidade. Utensílios ligados ao corpo, bem como vestimentas e objetos que possam valorizar determinadas partes e símbolos da sexualidade, passam a funcionar como elementos que produzem novos sujeitos femininos e masculinos. O poder vai operar através da fala uma vontade de dizer e saber fazendo os sujeitos falarem sem cessar sobre seus sexos, suas práticas sexuais e seus desejos mais proibidos. O corpo escondido embaixo de armaduras e imponentes vestimentas revela-se como um corpo exibido, dissimulado, que produz o dizer e a tentação. Na voz-off: "Foucault escreve: estamos em uma sociedade do sexo que fala.'(9'21'’-9'25) Assim, o poder que nos incita a falar (mesmo a fala mais interditada, a que sofre o filtro do tabu do sexo), que nos leva a dizer sim na enunciação, é o mesmo poder que opera sobre nós, individuando-nos para melhor nos controlar na sociedade coletiva: eis a tentativa de fazer de nossos corpos um lugar atravessado pelo poder que nos quer pastorar - seja pelo olhar do outro, seja através das técnicas de subjetivação instituídas pela igreja, pela clínica, pela escola ou pela ciência. E a fala é um dos importantes elementos que constituem tais técnicas, pois ela atravessa quase sempre a relação entre poder, discurso e enunciação na perspectiva filosófica foucaultiana.

$\mathrm{Na}$ aula inaugural do Collège de France ${ }^{3}$, bem como na Microfísica do poder, Foucault vai explorar com mais afinco estas questões, problematizando o funcionamento do poder, a constituição e apropriação dos discursos como a articulação poder-saber-enunciação mantém um vínculo intrínseco nas relações sujeito-estado, o que move e define nossas maneiras de ser nas sociedades historicamente definidas pelos discursos.

\section{Segundo movimento: do pensador ao militante}

A segunda sequência do filme traz fortes cenas do movimento de Maio de 68, onde se vê, em meio a fogos e fumaças, o confronto da polícia com os civis, sendo boa parte constituída por estudantes. Entre eles, o então professor de filosofia Foucault é um militante de esquerda que chegara a Paris para apoiar a causa estudantil. Conforme se vê

\footnotetext{
${ }^{3}$ FOUCAULT, M. A Ordem do Discurso: aula inaugural no Collège de France. Pronunciada em 2 de dezembro de 1970. São Paulo. Ed. Loyola: 1996.
} 
no documentário, meses depois, já na condição de diretor da Faculdade de Filosofia da Université de Vincennes, o filósofo apoia professores e estudantes radicalmente engajados na luta contra a imposição do Estado.

A historiadora Arlette Farge, em poucas palavras, vai avaliar a época como um contexto em que se participava dos debates nas ruas onde se lutava por questões como a liberdade, a utopia, a prisão, a felicidade, o intolerável, que para ela tinham grande importância enquanto tema político. Nesse contexto, para ela, Michel Foucault era uma grande figura, talvez igual ou mais que a figura do Jean-Paul Sartre. Ao lado de Sartre, Foucault vai às ruas (Figura 1) apoiar os movimentos sociais, grevistas, trabalhadores informais, vítimas de racismos, imigrantes - como se descreve na película - sendo então coerente com as questões que, há décadas, o filósofo procurava analisar: os sujeitos marginalizados e, institucionalmente, produzidos na divisão social desde há séculos, confrontados nas lutas de classes e oprimidos pelo poder institucionalizado, pelo Estado. É como militante que Foucault faz da filosofia e de sua própria fala um exercício de intervenção sobre as formas como se age nas questões sociais, enfrentando o poder do Estado minado nas instituições e nas relações intersubjetivas, contra sua forma de exclusão, sem banalizar suas ideias nem fazer delas uma pólvora explosiva na luta de classes. Militar e filosofar, nesse sentido, são atitudes de compreensão dos sujeitos; e a sociedade (seu vivo arquivo) constitui o laboratório de suas reflexões históricas. Para ele, o papel da filosofia é, portanto, interrogar o que somos em nossa sociedade contemporânea.

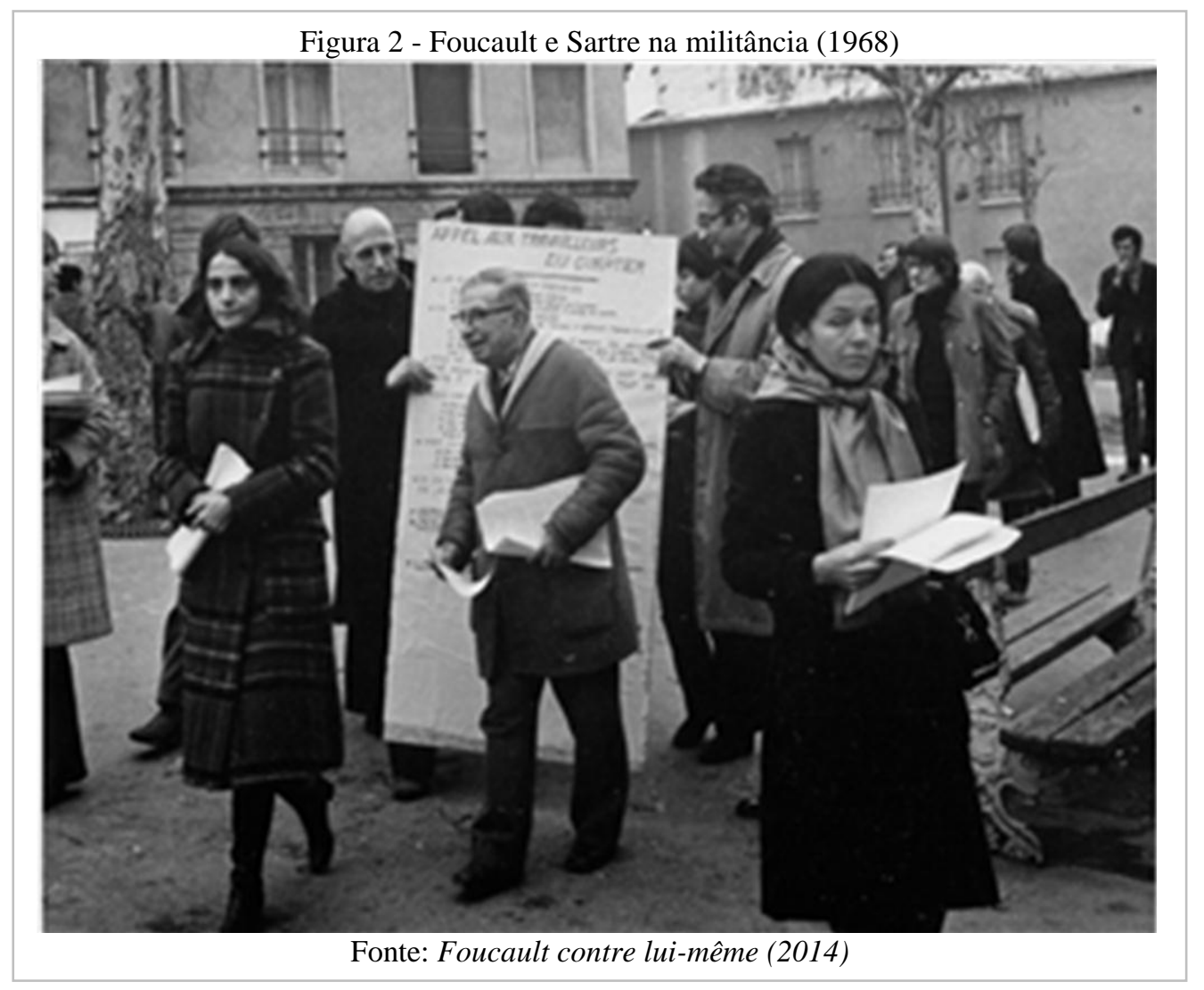




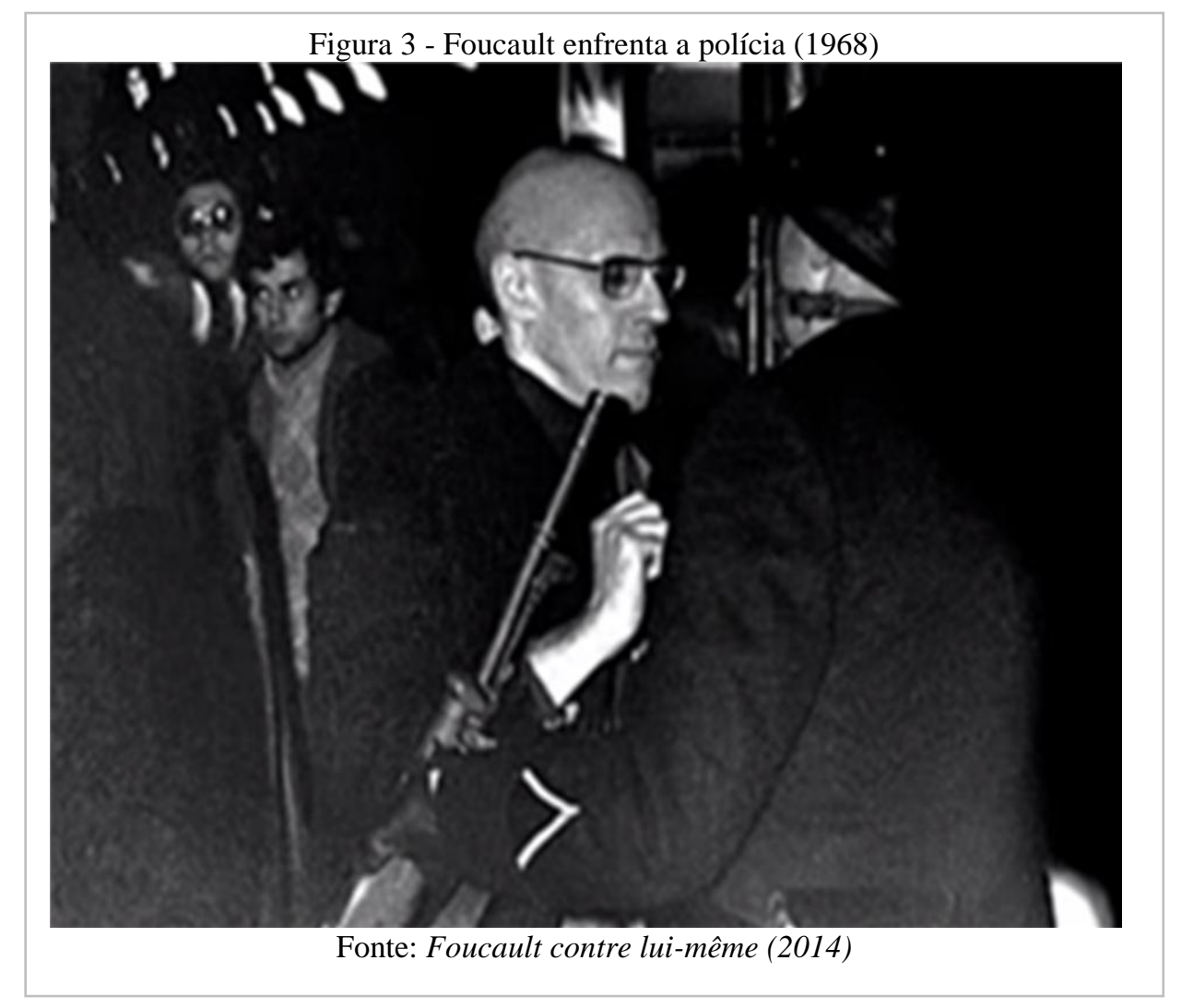

Foucault vai às ruas em tempos de cólera coletiva ou comoção social. Nesse sentido, la rue bouge contra toda uma ostensividade e truculência do Estado que se impunha contra o povo, os jovens de Maio de 68 (Figura 2). Talvez a lição da filosofia de Foucault, mas também a de tantos outros pensadores como J. P. Sartre, era entender em que medida o poder que se instaurou contra a sociedade era consequência das microfísicas que, outrora, ganharam força nas ruas, nos estabelecimentos, nos trocas de mercado, nas relações comerciais exploratórias, na constituição dos saberes disciplinares (escolas bibliotecas, igrejas, museus etc.) e, portanto, poderia ser questionado, enfrentado, derrubado, porque o poder é também um construto histórico, ele merge das relações políticas aliadas às práticas e aos discursos que o produzem. Tudo que se constrói numa sociedade pelo povo pode ser reconstruído em um ato heroicamente coletivo e contestatório, que ganha força nas ruas. Daí a razão de Foucault ter pegado seu megafone (a palavra em riste, a voz altiva em ato de guerra) e se colocado ao lado de estudantes, operários, cidadãos franceses, trabalhadores informais, civis, intelectuais, homens e mulheres, naqueles finais dos anos 1960. Simbolicamente, naquele contexto de lutas, Foucault emprestara sua voz em corpo que "marche dans les rues du Quartier Latin" fazendo a filosofia do Panteão sair dos bancos em direção às ruas.

No filme, vai-se afirmar que é a partir de 1970, através da cadeira História dos sistemas de pensamento (Histoire des systèmes de pensée) no Collège de France, que Foucault vai-se utilizar deste Panteão do saber e da intelectualidade francesa para transformá-lo, na medida em que, mesmo dentro dele, subverte suas "regras simbólicas" historicamente percebidas como lugar das ideias privilegiadas e não da militância e da práxis. Conforme defende G. Lagasnerie, no filme, para Foucault não há nenhuma luta mais importante que outra, nem uma ordem hierárquica para resolver os problemas da 
sociedade que justifique sua superposição, porque "todas as lutas são também centrais [...], não há hierarquia na política”. (16’18-16’28”)

Tal concepção de luta política, bem como de objeto teórico, é corroborada por Arlette Farge que afirma haver nos trabalhos foucaultianos um forte interesse pelos temas marginais. Os casos menores, as falas anônimas, a fala de um e de outro, as estratégias, os acontecimentos discursivos, os inúmeros e dispersos elementos do arquivo histórico têm seu valor histórico e constituem o complexo laboratório a partir do qual ele desenvolve seu pensamento. Como exemplo, Foucault percorreu as prisões e estudou o sistema prisional francês denunciando as práticas desumanas mantidas pelo Estado. Porém, em vez de estudar o sistema partindo dos documentos e da voz institucional - como tradicionalmente se fazia com os estudos da história oficial -, a equipe do filósofo distribuía questionários aos prisioneiros e a seus familiares, dando voz às vítimas do próprio regime, a fim de compreender as diferentes formas de sua atuação e denunciar à sociedade as ações do estando formando então outra opinião pública. Com G. Deleuze, Sartre e demais defensores dos direitos humanos, Foucault vai manifestar diante do Ministério da Justiça contra a negligência do Estado face aos prisioneiros, convocando a imprensa para tornar públicas aquelas questões que também eram de interesse de todos.

No Collège de France, através de seus seminários sobre os controles e a submissão dos corpos nas prisões e nas escolas, Foucault traduz e interpreta os problemas atuais de sua época como reflexo dos sistemas que, histórico e discursivamente, foram constituídos e normalizados como um regime de verdade. $\mathrm{O}$ conjunto de trabalhos dessa época está reunido no livro editado no Brasil Vigiar $e$ punir: nascimento da prisão (1975). É nesse livro que Foucault recupera a noção de panoptique imaginada no final do século XVIII pelos irmãos Jeremy Bentham e Samuel Bentham como um tipo de arquitetura carcerária circular com o objetivo de possibilitar ao vigilante (como uma câmera humana em $360^{\circ}$ ) ver todos os espaços onde houvesse detentos e assim ter controle de seus corpos numa espécie de máquina centralizada. Além do cárcere, tal projeto poderia ser aproveitado nas fábricas, usinas, asilos, hospitais e escolas. E o panóptico é atual e eficiente até nossos dias quando no mundo inteiro ele se alastrou e ganhou forma em médias e micro-câmeras presas nos prédios, portarias e postes prestes a nos seguir e nos condenar.

Para o filósofo, o dispositivo panóptico, no passado servia às instituições e ao estado de controle como um instrumento de vigilância dos indivíduos e disciplinarização dos corpos. Deuleuze (1988) afirma que a fórmula abstrata do panóptico não é 'ver sem ser visto'; na idéia de Foucault o panóptico se define como um controle óptico concreto, aplicado ao visível, que atravessa o enunciável, impondo assim uma conduta qualquer a um grupo qualquer de indivíduos.

Para G. Lagasnerie, Foucault acredita que a tarefa do intelectual face aos problemas e desafios da sociedade é ser porta-voz do presente e compreender o que se passa hoje, no presente da ação política e intelectual, evitando a luta pela própria luta.

O documentário nos apresenta exemplos claros desse tipo de arquitetura, evidenciando seu funcionamento escancarado às nossas vistas até hoje sem que, muitas vezes, não nos demos conta disso. As câmeras instaladas nos prédios, faculdades, lojas e inúmeros estabelecimentos de nosso tempo têm assumido a função do panóptico? Em que medida uma câmera escondida nesses locais públicos ou levadas a ver (Sorria, você está sendo filmado!) moldam nossos comportamentos impondo-nos um autoolhar/autocontrole ou olhar alheio vigilantes? Aí pode estar a atualidade do pensamento de Foucault que o documentário nos permite enxergar em nosso tempo sobre nós mesmos. 


\section{Terceiro movimento: que lugar para o homem?}

Desde os primeiros trabalhos de Foucault, a questão do sujeito e sua relação imprescindível com o discurso tornaram-se um problema privilegiado em seu pensamento. Basta acompanhar suas análises à luz da arqueologia a respeito do discurso da clínica, da loucura, da psiquiatria, da sexualidade ou do sistema prisional, como vimos até aqui, motivados pelos dois primeiros movimentos do documentário. Dentre a diversidade de temas, das contradições e dispersão do arquivo de que trata $G$. Lagasnerie, e diante das especificidades metodológicas inerentes a cada objeto, não se pode perder de vista a grande questão foucaultiana: o que somos hoje? Mais do que isso, afirma Foucault, é preciso lutar contra as formas de individuação e totalização que se nos impuseram há séculos, dado o regime de poder em suas diversas formas e nas mais distintas práticas de atuação. Nas palavras do filósofo:

Talvez, o objetivo hoje em dia não seja descobrir o que somos, mas recusar o que somos. Temos que imaginar e construir o que poderíamos ser para nos livrarmos deste "duplo constrangimento" político, que é a simultânea individualização e totalização própria às estruturas do poder moderno. (FOUCAULT, 1995, p.239)

A questão que intitula o terceiro movimento do documentário vai nessa direção: entender o lugar e a noção de homem nos sistemas de pensamento e constituição dos saberes. Ela nasce em As palavras e as coisas (Les mots et les choses) (1965) quando Foucault procura entender como se constituem os saberes de uma época e quais são as regras que os tornam legíveis. O filósofo vai estudar três grandes domínios desde a idade clássica (as ciências naturais e a biologia; a gramática e a filologia; a análise das riquezas e a economia), procurando desencavar o solo que originou certos tipos de saberes e discursos mantendo-os operantes até seus últimos momentos de circulação. Dito de outro modo, podemos afirmar que Foucault estava em vias de "descobrir" os processos de formação das ciências humanas, tendo em vista que, para ele, o homem foi uma invenção moderna que teve origem na biologia, na linguística e na economia política, ainda que seus fundamentos viessem dos três grandes campos que, respectivamente, deram existência a estas ciências. Em suas palavras, no filme, ele afirma: "Eu acredito que o homem foi, senão um sonho ruim, um pesadelo, ao menos uma figura bem particular, bem determinada, historicamente situada no interior de nossa cultura. [...] O homem é uma invenção...",

É bem verdade que o filme não aprofunda essa discussão, mas traça um panorama da obra mostrando como se dá a constituição dos saberes na passagem da idade clássica à moderna. De modo muito resumido como o panorama é apresentado, pode-se dizer que, dentre as distintas formas de transformações dos saberes, o filósofo estuda a relação entre as palavras e as coisas compreendendo três epistemes: a da semelhança, a da representação e a da interpretação a partir das quais o homem concebia as coisas desde a Idade Média, passando pela Renascença até a Modernidade.

Se na era da similitude o homem pensava as palavras como as coisas pela relação de fidedignidade entre o signo e o mundo, na Modernidade a ideia de referência

\footnotetext{
4 «Je crois que l'homme a été, sinon un mauvais rêve, un cauchemar, du moins une figure très particulière, très determinée, historiquement située à l'interieur de notre culture. [...] C'est une invention que l'homme...»(FOUCAULT: 31'37'’-31'54'). (São nossas todas as traduções e transcrições neste texto.)
} 
prevalece, havendo então uma concepção de palavra como representante da coisa no mundo. Espera-se, nessa ótica, que a semântica das palavras apresente correspondência na etimologia, na sintaxe e no texto, negando qualquer possibilidade de equívoco e arbitrariedade entre o significado (a imagem conceitual) e o significante (a coisa empírica) e os sujeitos que as empregam. Mas é na episteme da interpretação, emergente no início do século XIX, que a questão da arbitrariedade é posta em cena, pois se põem em questão aspectos exteriores ao signo como constituintes do sentido.

O problema da interpretação reclama para si - não só no campo da gramática geral mas também no interior das Ciências Humanas - o estatuto do social, do histórico e do sujeito como fundamental na apreensão do mundo simbólico, já que o homem tem apenas acesso ao mundo pela construção que ele faz de sua realidade. Logo, o mundo não é a palavra pela coisa, muito menos consegue ser representado pelas palavras; as coisas no mundo são interpretáveis e inventáveis. E o homem é uma de suas invenções. De todo modo, as coisas são estruturadas conforme um jogo de regras que as organizam. As teorias, as opiniões, as coisas, os objetos e as práticas obedecem a essas regras: trata-se de estruturas subjacentes ao pensamento e que são repetidas sem que os homens tenham consciência de sua existência, como se afirma na película. Segundo Didier Eribon, tal percepção vai servir de alvo de crítica da tradição marxista contra $A s$ palavras e as coisas, acusando Foucault como sendo um estruturalista, um filósofo de direita que negava as ações humanas e a práxis, enfim, um anti-humanista.

Contra críticas como essas, Foucault vai mostrar de forma mais enfática vinte anos depois, através das pesquisas que dão origem aos volumes de História da sexualidade, que o homem sempre se fez presente em suas questões desde a História da loucura. Nos estudos do fim do anos 1970 e início de 1980, ele mostra como o homem, desde a antiguidade clássica, se constitui enquanto sujeito através das cuidados de si.

É fazendo esporte, exercícios, tendo interesses pela medicina, cuidando de si mesmo, que o homem se mostra como um sujeito historicamente preocupado com seu corpo e consigo mesmo. Isso não significa que Foucault se manteve linearmente coerente em sua abordagem; frequentemente o filósofo estava reelaborando suas reflexões em torno de seus objetos. O que é sintomático da época no pensamento de Focault é a questão das técnicas de subjetivação refletidas pelo francês como um fenômeno relacionado à identidade do homem ocidental em atuante em sua contemporaneidade. Conforme nos leva a pensar Eribon, a viagem à Grécia e aos Estados Unidos, a luta pelos direitos civis, os movimentos gay ${ }^{5}$ e de contra-cultura, bem como os conhecimentos grego-latinos antigos, vão servir de espécie de grande arquivo no interior do qual ele vai desenvolver questões em torno da ideia de governo de si mesmo. Nesta problemática se inscreve, portanto, o lugar do homem como um grande problema em seus estudos. Nesse sentido, contrapondo-o à natureza do indivíduo enquanto sujeito biológico e psíquico, o sujeito foucaultiano se fundamenta na história; o sujeito é histórico e, por isso, é passível de transformação política.

\section{Quarto movimento: uma vida nas margens, um lugar no centro}

\footnotetext{
${ }^{5} \mathrm{O}$ documentário apresenta uma série de imagens de militantes nas ruas de São Francisco, na Califórnia, EUA. Sobre este contexto histórico, sobretudo no que diz respeito ao movimento Gay Pride dos anos 1960 e 1970, o filme Harvey Milk (2008) dirigido por Gus van Sant, que conta a história do ativista político homônimo pela causa GLBT naquele estado americano, serve de bom documento para entender um pouco mais das causas e temas políticos da época às quais Foucault também fazia face ainda que fosse in loco na década de 1980. Ele não era alheio às causas e às lutas das "minorias", seja na França, seja nos EUA ou alhures.
} 
Se as manifestações de Maio de 68 em Paris serviram a Michel Foucault como cenário de resistência às injustiças institucionalizadas - palco de militância intelectual e laboratório de suas reflexões filosóficas - não seria diferente em meio a um novo modo de vida na América subversiva dos anos 1980 que ele passava a experimentar quando professor da Berkelay University na Califórnia. Então convidado do professor americano Leo Bersani na década de 1970, o pensador francês fará dessa experiência um rico momento de suas reflexões filosóficas em torno do sujeito, da sexualidade, dos cuidados de si, da relação de uns com outros, da liberdade, o uso de drogas e da expressão cultural, sobretudo na cidade de São Francisco conhecida como centro da revelação cultural gay americana até hoje. Para Bersani, ainda que o modo de vida californiano tenha muito encantado Michel Foucault, ele não estava necessariamente interessado pela vida e liberdade sexual, mas pelo modo de se relacionar com os outros, o que lhe parecia muito diferente daquele visto na sociedade francesa ou mesmo europeia à época.

O filme revela, neste último movimento, um filósofo irreverente que, ainda que ocupasse um lugar privilegiado na comunidade intelectual francesa (ou melhor, no Panteão do saber, o Collège), transitava nas margens: seja em sentido metafórico quando em muitas de suas posições face à construção do conhecimento se rompiam com a tradição, com o discurso científico oficial - seja no sentido literal, ao experimentar drogas como LSD após suas inúmeras viagens aos EUA mesmo na idade dos 50, como nos leva a entender o documentário. Segundo Bersani, "o fato de ser professor no Collège de France o fazia muito famoso no mundo inteiro, e por isso ele recebia convites de todos os lugares onde ele poderia ser quem era completamente diferente do que identificamos como professor do Collège de France." ${ }^{6}$ Como se escuta em voz-off, Foucault é "o pior produto do sistema universitário francês. Ele foi formado em excelência.[sic]" Nesse sentido, ao ser formado como aluno exemplar das instituições de educação e estado francês, Foucault é o maior exemplo das técnicas de subjetivação e domesticação dos corpos engendradas por uma sociedade regida pelas relações de poder. Na medida em que ele ascende os espaços institucionais que lhe formavam, ele toma plena consciência das relações de poderes das quais faz parte. Porém, isso não lhe impede de, dentro delas, se transformar, resisti-las e tentar modificá-las, utilizando a própria instituição e o poder simbólico que lhe contornavam. Foi o que ele fez até o fim de sua vida, falando e produzindo seus escritos dentro da instituição universitária, por vezes contra ele mesmo, porém para nós todos ainda hoje, para que lutemos contra os rótulos identitários que as instituições, os discursos e as técnicas de subjetivação insistem em nos pregar.

\section{Do epílogo: analogia do passado, história do presente}

Nos últimos minutos do documentário, Georges Didi-Huberman traz uma reflexão bem original do trabalho do Foucault sem se preocupar em abordar este ou aquele conceito. De modo geral, o historiador define o trabalho do filósofo como uma espécie de analogia, conceitos e símbolos que levam seu leitor a reconhecer seu tempo, a sociedade de que faz parte e a si mesmo em seus escritos, ainda que muitas vezes Foucault tenha se reportado à história de longas e média durações; ainda que ele tenha falado de outros tempos e outros sujeitos. As ideias do filósofo, nesse sentido, acabam nos servindo de espelho, para onde olhamos e podemos reconhecer a atualidade de seus

\footnotetext{
${ }^{6}$ «Le fait d'être professeur au Collège de France le rendait très celèbre partout dans le monde, et dont il recevait des invitations partout où il pouvait être qui était tout à fait different de ce qui on identifie comme professeur au Collège de France.» (Bersani : 42'31'"-42'51'’).
} 
conceitos e seus objetos de análise na atualidade de nosso tempo, levando-nos a pensar o nosso presente. Daí advém a comparação que Didi-Huberman faz entre o filósofo e o poeta boêmio: "parece-me que ele é herdeiro de Baudelaire, do Baudelaire da imaginação", pelo fato de Foucault ter desenvolvido relações conceituais pouco perceptíveis para outros pensadores, uma espécie de analogia fecunda que possa revelar o impensável.

O filme se encerra com as últimas palavras de Didi-Huberman, dentre as quais aquela de que é a imagem que pode atravessar as fronteiras. Para ele, as imagens, as ideias, a construção do saber não devem se territorializar; elas precisam sempre romper com seu lugar de origem. E assim fizeram as ideias de Michel Foucault quando romperam os limites tradicionais do Panteão filosófico que, por muitos anos, funcionou como um panóptico da ciência... pouco sensível a escutar as vozes de seu entorno, principalmente aquelas vozes que ecoavam nas retas ruas arquitetadas pelo poder para nos vigiar e depois punir.

\section{Referências}

CAILLAT, F. Foucault contre lui-même. Paris : INA, 2014. DVD. Durée totale: 2h03. Format Image. Version Originale Française. 2014.

CARBONESI, L. Geoffroy de Lagasnerie: uma polêmica leitura neoliberal de Foucault. Rev. Brasileira de Ciências Sociais. Vol. 29, n. 84, p.195-199, 2014. Disponível em: <http://www.scielo.br/pdf/rbcsoc/v29n84/13.pdf>. Acesso em: 18 nov. 2014.

DELEUZE, G. Foucault. Trad. Claudia Sant'Anna Martins. São Paulo: Editora Brasiliense, 1988.

FERNANDES, C. A. Discurso e sujeito em Michel Foucault. São Paulo: Intermeios, 2012.

FOUCAULT, M. Vigiar e punir: nascimento da prisão. 20 ed. Trad. de Raquel Ramalhete. Petrópolis: Vozes, 1999.

FOUCAULT. Michel. O sujeito e o poder. In: DREYFUS, H.; RABINOW, P. Michel Foucault, uma trajetória filosófica: para além do estruturalismo e da hermenêutica. Trad. Vera Porto Carrero e Antônio Carlos Maia. Rio de Janeiro: Forense Universitária, 1995, p. 231-249.

FOUCAULT, M. A Ordem do Discurso: aula inaugural no Collège de France. Pronunciada em 2 de dezembro de 1970. São Paulo. Ed. Loyola: 1996.

FOUCAULT, M. As palavras e as coisas: uma arqueologia das Ciências Humanas. Trad. Salma Tannus Muchail. São Paulo: Martins Fontes, 2007.

LAGASNERIE,G. La dernière leçon de Michel Foucault: sur le néolibéralisme, la théorie et la politique. Paris : Editions Fayard, 2012.

LAGASNERIE, G. A última lição de Michel Foucault: sobre o neoliberalismo, a teoria e a política. Trad. André Telles. São Paulo: Três Estrelas, 2013.

VEYNE, P. Foucault : sa pensée, sa personne. Paris: Albin Michel, 2008. 
